\title{
Correlação entre os Niveis Séricos de Leptina, Estradiol e Hormônio Folículo Estimulante em Mulheres com Supressão Medicamentosa da Função Hipotisária
}

\author{
Correlation between Serum Leptin, Estradiol and Follicle Stimulating Hormone Levels in \\ Women with Medication-induced Suppression of Pituitary Function
}

Autor: Márcio Gomes Vilela

Orientador: Prof. Dr. Selmo Geber

Dissertação de Mestrado apresentada ao Departamento de Pós-Graduação da Faculdade de Medicina da UFMG, em 7 de outubro de 2003

A leptina é uma proteína codificada pelo gene $o b$, que interfere no eixo reprodutivo. Alguns autores afirmaram que o estradiol e o FSH podem influenciar a produção da leptina pelos adipócitos. No entanto, os resultados ainda são conflitantes. Para avaliar essas possíveis relações, foram estudadas em estudo transversal e prospectivo na Clínica Origen, em Belo Horizonte-MG, 64 pacientes submetidas à hiperestimulação ovariana controlada por FSH recombinante (para reprodução assistida, devido a fator masculino ou tubário) e 20 pacientes em uso de valerato de estradiol, por não apresentarem resposta à indução da superovulação em ciclos anteriores ou apresentarem FSH > 15mUI/ $\mathrm{ml}$ no terceiro dia do ciclo menstrual, tendo sido utili- zado previamente o análogo de GnRH. Observou-se que os niveis de leptina correlacionaram-se com o IMC, embora não tenham influenciado a taxa de crescimento desses hormônios. Verificou-se correlação positiva entre os niveis de estradiol e leptina em ambos os grupos. As taxas de crescimento da leptina foram mais altas nas mulheres que tiveram ciclos induzidos com FSH recombinante do que nas não tratadas. Concluiuse que a leptina correlacionou-se com o IMC e que tanto o FSH quanto o estradiol podem ser importantes reguladores da produção de leptina nas mulheres.

Palavras-chave: Leptina. Reprodução assistida. Obesidade. Índice de massa corporal.

\section{Transmissão Perinatal do HIV-1 entre Participantes do Programa de Controle do HIV/AIDS no Sul do Brasil: um Estudo de Coorte}

\author{
Perinatal transmission of HIV-1 Among the Participants in a Program of HIV/AIDS \\ Control in the South of Brazil: a Cohort Study
}

Autor: Regis Kreitchmann

Orientador: Dra. Sandra Costa Fuchs

Tese de Mestrado apresentada no Programa de Pós-Graduação em Medicina: Ciência Médicas da Universidade Federal do Rio Grande do Sul em 7 de fevereiro de 2003

Estudo realizado no Centro Municipal de Atendimento em Doenças Sexualmente Transmissiveis e AIDS de Porto Alegre, Secretaria Municipal da Saúde

Objetivo: Determinar a taxa e os fatores preditores da transmissão perinatal entre gestantes portadoras do HIV-1.

Desenho: Estudo de coorte incluindo todas as gestantes ou puérperas portadoras do HIV-1 e participantes do programa de controle da transmissão perinatal HIV, no Centro Municipal DST/AIDS, RS, Brasil, entre janeiro de 1997 e dezembro de 2000.

Métodos: Gestantes HIV-1 positivas foram arroladas no início do atendimento pré-natal ou puérperas até 10 dias após o parto, sendo acompanhadas durante a gravidez, até aproximadamente 24 meses após o parto, assim como seus recém-nascidos. As participantes foram entrevistadas, utilizando-se um questionário padronizado, no arrolamento, nas reavaliações durante o atendimento pré-natal, no puerpério e nas consultas pediátricas. Realizaram-se a contagem de linfócitos CD4, carga viral para HIV (PCR-RNA), anti-HCV, HBSAg e VDRL. Investigaram-se características demográficas, socioeconômicas, reprodutivas, comportamentais, relacionadas à contaminação pelo HIV e adesão ao tratamento com anti-retrovirais (ARV). Determinou-se a adesão ao tratamento com antiretrovirais a partir da informação sobre o emprego de ARV durante a gestação, no trabalho de parto e, após o parto, para o recém-nascido. Considerou-se como adesão completa quando a mãe e o recém-nascido receberam pelo menos $80 \%$ das doses de ARV prescritas nas três situações. Consideraramse infectadas pelo HIV as crianças com dois testes positivos para RNA viral, ou um teste Elisa, realizado com duas técnicas diferentes e confirmado pela imunofluorescência indireta após 18 meses de vida.

Resultados: Avaliou-se a transmissão perinatal do HIV1 em 343 crianças (95\% do total arrolado), o que resultou em uma taxa de transmissão perinatal de $3,2 \%$ (IC 95\% 1,7-5,8\%). A adesão completa ao tratamento com anti-retrovirais na gestação foi de $75,3 \%$. Entre as variáveis investigadas apenas os valores de carga viral 
materna iguais ou maiores que 10.000 cópias $/ \mathrm{ml}$ $(\mathrm{RR}=11,27$; IC95\%: 1,38-92,23) e principalmente superiores a 100.000 cópias $(\mathrm{RR}=19,1$; IC95\%: 1,82-200,57) associaram-se com a transmissão do vírus ao recémnascido. $\mathrm{Na}$ análise multivariada a carga viral permaneceu significativa e independentemente associada à transmissão perinatal $(\mathrm{OR}=2,72$ para o aumento de 1 log no número de cópias virais; IC95\%: 1,17-6,50).

Conclusão: Em gestantes expostas ao tratamento com anti-retrovirais durante a gestação, no parto e cujos recém-nascidos receberam ARV a taxa de transmissão perinatal do HIV-1 foi baixa e apenas os valores de carga viral foram preditores da transmissão. A transmissão perinatal do HIV-1 pode ser evitada através da disponibilização dos antiretrovirais, pela alta taxa de adesão pelas gestantes e por seus filhos, assim como a fornecimento do aleitamento artificial para o recémnascido.

Palavras-chave: Fatores de risco. HIV-1. Transmissão perinatal. Carga viral

Keywords: Risk factors. HIV-1. Perinatal transmission. Viral load 